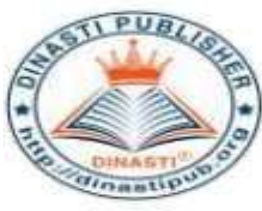

\title{
THE EFFECT OF COMPETENCE AND TRANSFORMATIONAL LEADERSHIP STYLE ON THE MOTIVATION AND ITS IMPLICATIONS ON TEACHERS PERFORMANCE AT 01 AND 02 NORTH PETUKANGAN ELEMENTARY SCHOOL
}

\author{
Triadhy Wicaksono ${ }^{1}$, Farida Elmi ${ }^{2}$, Muhammad Havidz Aima ${ }^{3}$ \\ 1) Magister of Management, Lecturer of Postgraduate, Mercu Buana University, Indonesia \\ 2) Magister of Management, Lecturer of Postgraduate, Mercu Buana University, Indonesia \\ ${ }^{3)}$ Magister of Management, Lecturer of Postgraduate, Mercu Buana University, Indonesia
}

\begin{tabular}{|c|c|}
\hline $\begin{array}{l}\text { ARTICLE INFORMATION } \\
\text { Received: } 25 \text { January } 2019 \\
\text { Revised: } 30 \text { January } 2019 \\
\text { Issued: } 9 \text { February } 2020 \\
\text { (filled in by Editor) } \\
\text { Corresponding author: first author } \\
\text { E-mail: } \\
\text { triadhykelik@ gmail.com } \\
\text { farida.elmi@ @mail.com } \\
\text { havidz.aima@mercubuana.ac.id }\end{array}$ & $\begin{array}{l}\text { Abstract: The purpose of this study is to study and } \\
\text { explain the role of competence and transformational } \\
\text { leadership styles on the performance of } 01 \text { and } 02 \text { North } \\
\text { Petukangan elementary school teachers, mediated by } \\
\text { motivational variables. The research method uses } \\
\text { quantitative and part of this research is } 01 \text { and } 02 \text { North } \\
\text { Petukangan elementary school teachers who gathered } 52 \\
\text { people. The sample selection is done by saturated sampling } \\
\text { techniques or census sampling so as to make all members } \\
\text { of the study as research samples. Data collection techniques } \\
\text { using interviews and questionnaire instruments. Survey } \\
\text { instruments were sent to } 01 \text { and } 02 \text { North Petukangan } \\
\text { elementary school teachers. Data were analyzed using a } \\
\text { structural consolidation model (SEM) with the Smart PLS } \\
\text { software program version 3.2.8. This study revealed } \\
\text { significant competence that were significant to teacher } \\
\text { performance and transformational leadership style had a } \\
\text { significant positive effect on teacher performance. } \\
\text { Competence and leadership styles change. In addition, } \\
\text { motivation variables do not mediate competence and } \\
\text { transformational leadership styles on teacher performance. } \\
\text { Keywords: Competence, Transformational Leadership } \\
\text { Styles, Motivation, And Teacher Performance. }\end{array}$ \\
\hline
\end{tabular}

\section{INTRODUCTION}

The 1945 Constitution mandates that the state is obliged to educate the nation's life. The mandate to educate the nation's life is realized through the implementation of the national education system. According to Law No. 20 of 2003 concerning the National Education System (SISDIKNAS), education is a conscious and planned effort to create an atmosphere of learning and learning process so that students actively develop their potential to have religious spiritual strength, self-control, personality, intelligence, noble character, and the necessary skills himself, society, nation and state. Education is a science while teaching is an art. The art teaching is about creativity which depedent on knowledge of effective techniques and also upon the application of these techniques (Wiratih and Aima, 2017). 
In general the value of teacher competence tests, both kindergarten teachers, elementary school teachers, junior high school teachers, and senior high school teachers experienced an increase, but in 2017, Competence tests elementary school teachers actually experienced a decline from 63.80 to 62.22. Although in general the average value of teacher Competence tests has increased, overall the average value is still far from what is expected. The average teacher performance evaluation in 01 and 02 North Petukangan has decreased. Although simultaneously in the 2017/2018 school year the average value of teacher performance appraisal reached 80 , but it has not increased significantly from period to period.

The pre-survey results show that there are three variables that have the lowest influence in influencing the performance of 01 and 02 North Petukangan elementary school teachers, namely competence variable (32\%), transformational leadership style (36\%), and work motivation (40\%) compared to variables such as work environment, work discipline, work stress, and other variables.

In addition, there are differences in the results of some previous studies between competence variables, transformational leadership style, and work motivation on teacher performance. Based on the description above, the researcher will examine in depth the "Effect of Competence and Transformational Leadership Styles on Motivation and Its Implications on Teacher Performance at 01 and 02 North Petukangan Elementary School".

Based on the research problem formulation outlined above, the objectives to be achieved in this study are to find out and explain, among others: (1) The effect of competence on the work motivation of 01 and 02 North Petukangan elementary school teachers; (2) The effect of transformational leadership style on the work motivation of 01 and 02 North Petukangan elementary school teachers; (3) The effect of competence on the performance of 01 and 02 North Petukangan elementary school teachers; (4) The effect of transformational leadership style on the performance of 01 and 02 North Petukangan elementary school teachers; (5) Simultaneous influence of competence and transformational leadership style on the work motivation of 01 and 02 North Petukangan elementary school teachers; (6) Simultaneous influence of competence, transformational leadership style, and work motivation on the performance of 01 and 02 North Petukangan elementary school teachers; (7) The effect of work motivation on the performance of 01 and 02 North Petukangan elementary school teachers; (8) Significance of work motivation in mediating the effect of competence and transformational leadership styles on the performance of 01 and 02 North Petukangan elementary school teachers.

\section{LITERATURE REVIEW}

\section{Competence}

According to Government Regulation No. 74 of 2008 concerning Teachers, Competence is a set of knowledge, skills and behaviors that must be possessed, internalized, mastered, and actualized by the Teacher in carrying out professional tasks.

According to Marwansyah (2014) competence are knowledge, skills, personality characteristics, and attitudes that enable employees to carry out tasks and roles in their work.

From the above definition, it can be concluded From these various opinions it can be explained that competence is the ability to carry out or do a job based on knowledge, skills, and attitudes that must be possessed and mastered by teachers in carrying out their professional tasks.

Based on Government Regulation No. 74 of 2008 concerning Teachers, there are four dimensions namely pedagogic competence, personal competence, professional competence, and social competence.

\section{Transformational Leadership Style}

According to Robbins and Judge (2015) transformational leadership is the ability of leaders who inspire followers to transcend their own self-interests to benefit the organization. According to Yukl (2015) a leader transforms and motivates followers by making them more aware of the 
importance of the results of a job; encourage them to prioritize the organization or team rather than self-interest; and activate their needs at a higher level.

Based on some of the opinions above it can be concluded that the characteristics of transformational leaders are must have a strong desire to achieve organizational goals; diagnostic expertise; and always take the time and pay attention in an effort to solve the problem.

Bass and Avolio (2002) state that the components of transformational leadership consist of four leadership dimensions, namely charisma, inspirational motivation, intellectual stimulation, and individual consideration.

\section{Motivation}

According to Rivai et. al. (2014) motivation is a set of attitudes and values that influence individuals to achieve specific things in accordance with individual goals. Attitudes and values are an invesible that provides the power to encourage individuals to behave in achieving goals.

According to Mangkunegara (2015) motivation is a condition or energy that drives employees to be directed or aimed at achieving organizational goals. According to Robbins and Judge (2015) said that motivation is a process that clarifies the intensity, direction, and perseverance of an individual to achieve his goals.

Based on some of the above notions, it can be concluded that the notion of motivation is the employee's response to a number of statements regarding the overall effort arising from within the employee so that the impetus for work grows and the goals desired by the employee can be achieved.

According to McClelland in Sutrisno (2016), work motivation variables consist of three dimensions, namely the need for achievement, the need for affiliation, and the need for power.

\section{Teacher Performance}

Performance is the result of someone's work at a time. According to Kasmir (2017), performance is the result of work and work behavior that has been achieved in completing tasks and responsibilities given within a certain period. Teacher performance according to Asf and Mustofa (2013) is the work that can be achieved by a teacher in an educational institution or madrasa in accordance with their duties and responsibilities in achieving educational goals.

Based on Law number 20 of 2003 concerning the National Education System in article 39 paragraph 2 states that the task of the teacher is to plan and implement the learning process, assess learning outcomes, conduct mentoring and training.

Based on some of the above understanding, it can be concluded that the understanding of teacher performance is the level of success of teachers in carrying out their work tasks in the scope of education based on skills and expertise.

According to Riduwan (2014), teacher performance can be measured in five dimensions, namely ability to work, initiatives at work, timeliness, quality of work results, and quality of work results

\section{Theoretical framework}

Research conducted by Rahim et. al (2017) states that competence has a significant effect on motivation. Research conducted by Ahmad et. al. (2014) produces that transformational leadership style significantly influences work motivation. Meswantri and Awaludin (2018) also stated that employee competence had a significant effect on employee performance. Sinaga et. al. (2018) states that the transformational leadership style has a significant influence on employee performance. Work motivation affects a person's performance at work, this is evidenced by research conducted by Aima, Adam, and Ali (2017), Nugroho et. al. (2015) and Shahzadi et. al. (2014).

Based on the explanation of the relationship between the variables described above, it can be used as a framework of thought in the form of a chart that will be presented in Figure 1. 


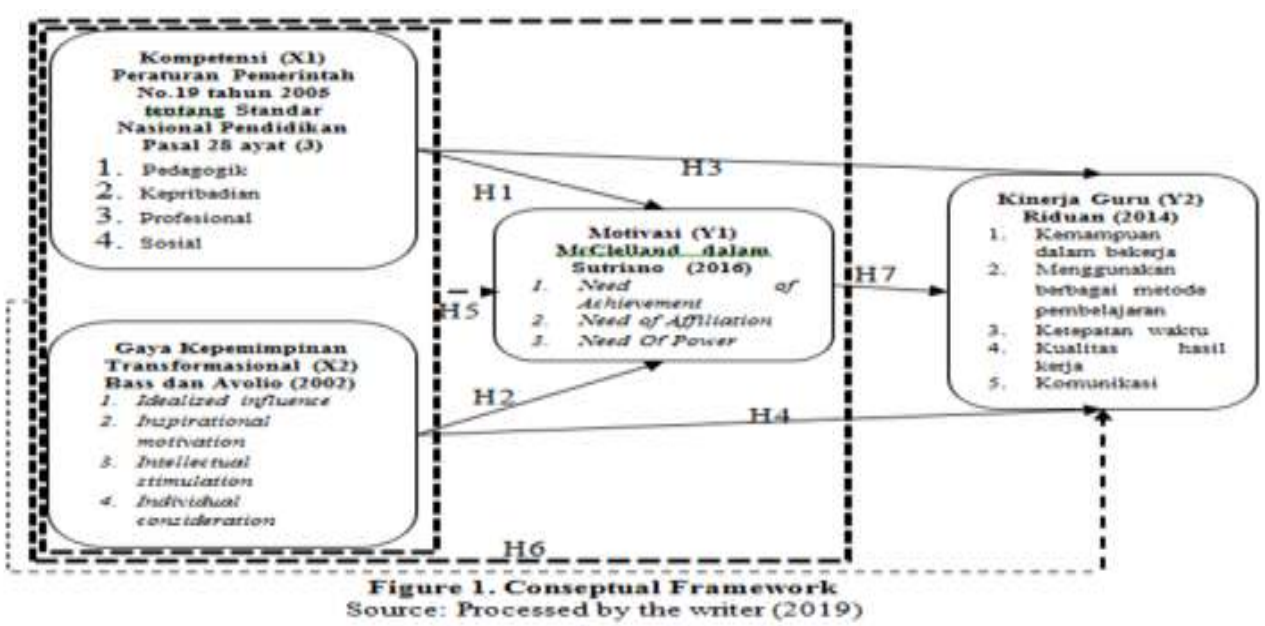

\section{Hypothesis}

Based on the research objectives and theoretical basis and the formulation of the problem previously described, the hypotheses proposed in this study are as follows:

H1: Competence has a significant effect on work motivation

H2: Transformational leadership style has a significant effect on work motivation

H3: Competence has a significant effect on teachers performance

H4: Transformational leadership style has a significant effect on teachers performance

H5: Competence and transformational leadership style simultaneously have a significant effect on work motivation

H6: Competence, transformational leadership style, and motivation simultaneously have a significant effect on teachers performance

H7: Motivation has a significant effect on teachers performance

H8: Motivation significantly mediates competence

\section{RESEARCH METHODS}

This type of research is quantitative research using primary data in the form of surveys. This study was designed with the aim of being able to understand, explain, and analyze the correlation between the independent variables and the dependent variable. The independent variables in this study are Competence (X1) and Transformational Leadership Style (X2). The dependent variable is a variable that is influenced by the independent variable. The dependent variable in this study is Motivation (Y1) and Teachers Performance (Y2).

Table 1 . Definition of Variable Operations

\begin{tabular}{|c|c|}
\hline Variables & Dimension \\
\hline Competence (X1) & 1. Pedagogical Competence \\
\hline \multirow{3}{*}{ Government Regulation No. 74 of 2008} & 2. Personality competence \\
\hline & 3. Social Competence \\
\hline & 4. Professional Competence \\
\hline Transformational Leadership Style (X2) & 1. Idealized Influence \\
\hline \multirow{3}{*}{$\begin{array}{l}\text { Bruce J. Avolio and Bernard M. Bass } \\
(2002)\end{array}$} & 2. Inspirational Motivation \\
\hline & 3. Intellectual stimulation \\
\hline & 4. Individual Consideration \\
\hline Motivation (Y1) & 1. Need for achievement \\
\hline \multirow{2}{*}{ McClelland in Sutrisno (2016) } & 2. Need for affiliation \\
\hline & 3. Need for power \\
\hline Teachers Performance (Y2) & 1. Ability \\
\hline \multirow{4}{*}{ Riduan (2014) } & 2. Initiatives \\
\hline & 3. Timeliness \\
\hline & 4. Quality of work \\
\hline & 5. Communication \\
\hline
\end{tabular}

Source: Primary data processed (2019) 
Population and sample

In this study the population used was all teachers in 01 and 02 North Petukangan elementary school, amounting to 52 people. The sample in this study used a saturated or census sampling technique where subjects were taken from all teachers at 01 and 02 North Petukangan elementary school who had a limited sample and made all members of the population a research sample. The number of samples in this study were 52 people.

\section{Method of Analysis}

In looking for the effect of each variable, researchers used Statistical Software, SmartPLS version 3.2.8. The data analysis technique used in this quantitative study uses descriptive statistics and inferential statistical analysis. Descriptive statistics are statistics used to analyze data by describing or describing data that has been collected as it is without intending to make generally accepted conclusions or generalizations (Sugiyono, 2016). In accordance with the hypotheses that have been formulated, then in this study inferential statistical data analysis is measured using SmartPLS (Partial Least Square) software starting from measurement models (outer models), structure models (inner models) and hypothesis testing.

\section{Research Results and Discussion}

The results of this study will be explained by descriptive statistics and inferential statistics using secondary data and primary data obtained during the study.

\section{Evaluation of Measurement Model (Outer Model)}

Done to find out the validity and reliability that links between indicators with latent variables. The loading factor value used in this study is $>0,5$ so that if the loading factor value $<0,5$ in the calculation results of the measurement model (outer model) will be excluded from the model.

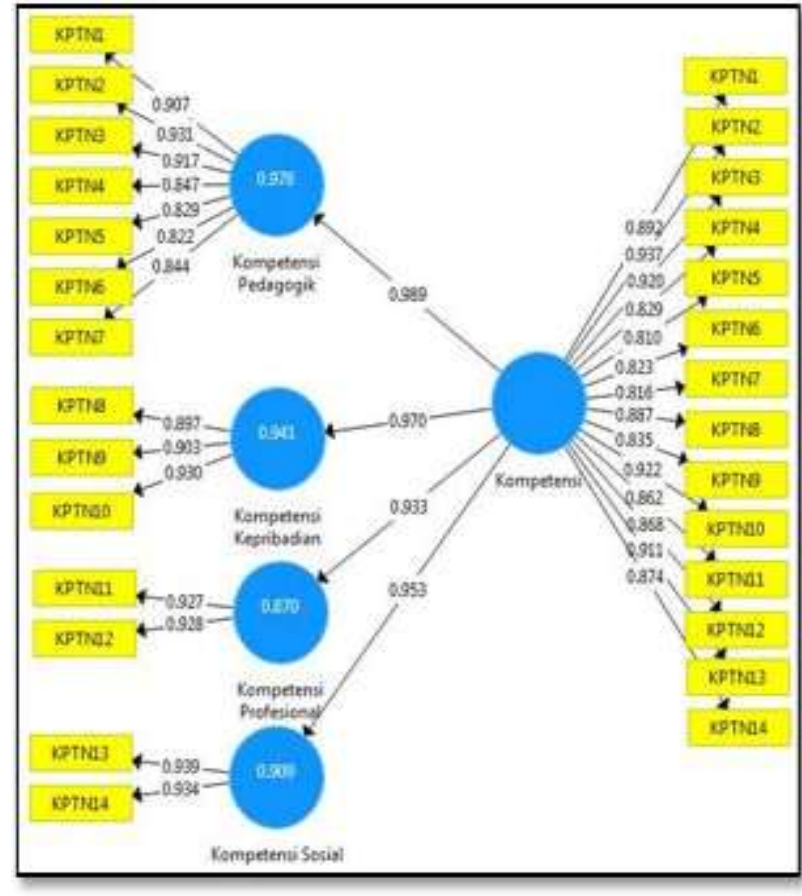

Figure 2. Outer model Competence variable leadership style variable

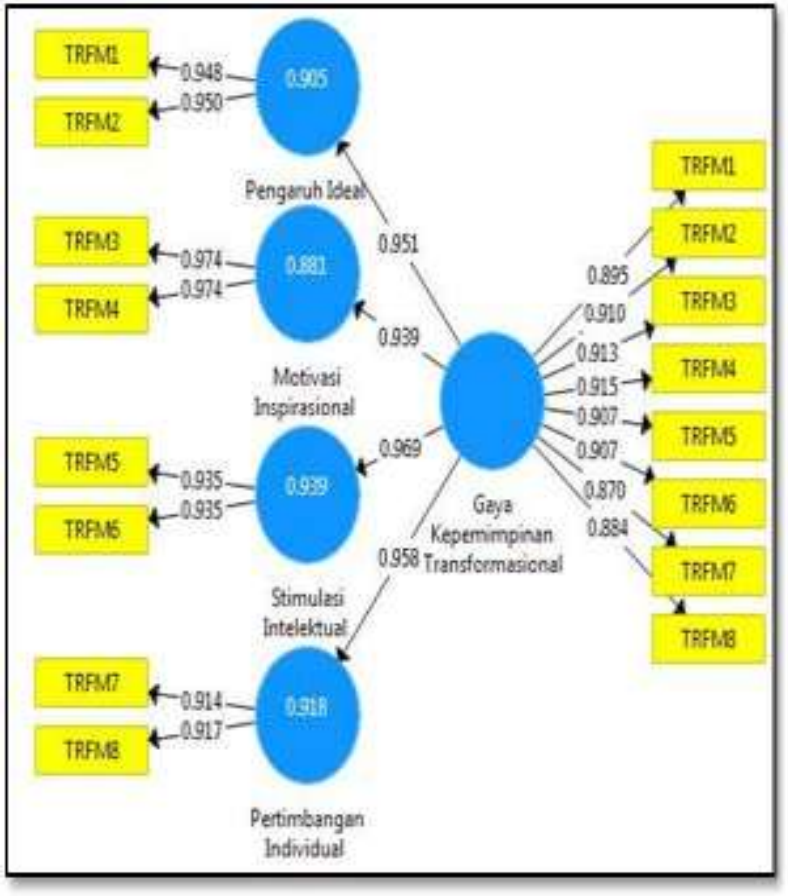

Figure 3 . Outer model of transformational 


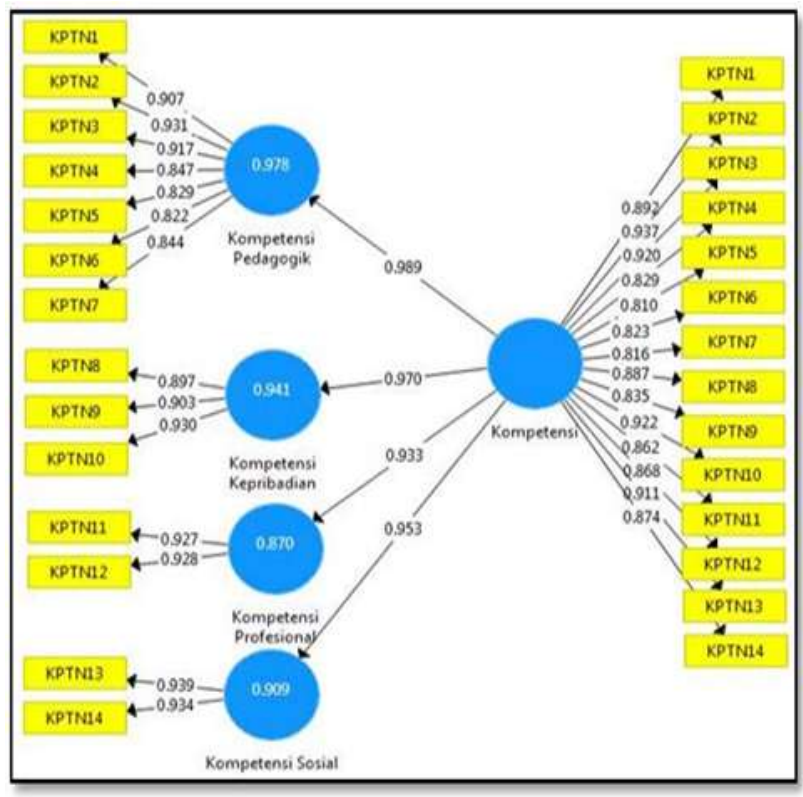

Figure 4. Outer models of work motivation variable

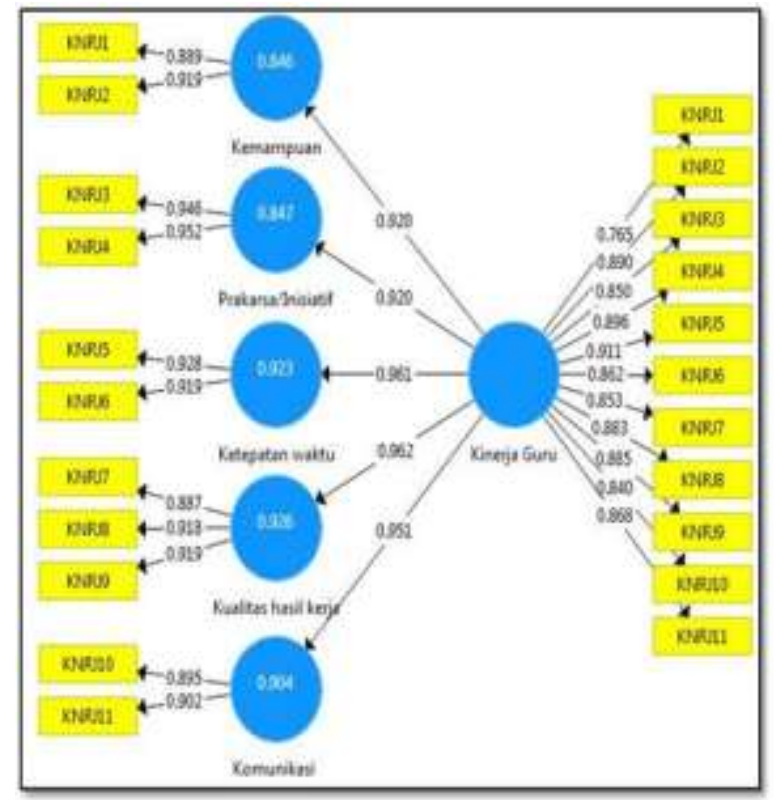

Figure 5. Outer model of teachers performance variable

In addition, the AVE value is also used as an indicator of the assessment of convergent validity. According to Hair et. al. (2014) the AVE value must be >0,5, Table 2 shows the AVE value.

Table 2. Value Average Variance Extracted (AVE) Each Variable

\begin{tabular}{lc}
\hline \multicolumn{1}{c}{ Variable } & Average Variance \\
\hline Comptracted & 0.759 \\
\hline Transformational Leadership Style & 0.810 \\
\hline Motivation & 0.797 \\
\hline Teacher Performance & 0.749
\end{tabular}

Source: Researcher processed data (2019)

Evaluation of convergent validity from internal consistency reliability checks can be seen from the Cronbach's Coefficient Alpha and Composite Reliability $(C R)$ values shown in the following table 3.

Table 3 . Cronbach Coefficient Alpha Value and Composite Reliability (CR)

\begin{tabular}{lcc}
\hline \multicolumn{1}{c}{ Variable } & Cronbach's Coefficient Alpha & Composite Reliability (CR) \\
\hline Competence & 0.975 & 0.978 \\
\hline $\begin{array}{l}\text { Transformational } \\
\text { Leadership Style }\end{array}$ & 0.967 & 0.972 \\
\hline Motivation & 0.957 & 0.965 \\
\hline Teacher Performance & 0.958 & 0.964 \\
\hline Source: Researcher processed data (2019)
\end{tabular}

In table 2 it is known that the Cronbach's Coefficient Alpha value and Composite Reliability value for all research variables are more than 0.80 or even close to 1 . These values have exceeded the standard, respectively $>0.6$ and $>0.7$, so that all variables in the study are declared reliable. 


\section{Evaluation of Structural Model ( Inner Model )}

Based on calculations using the calculate SmartPLS version 3.2.8 bootstrapping showed the path coefficients which describes the strength of the relationship between the constructs/variables as shown in Table 4 and Figure 6

\begin{tabular}{|c|c|c|c|c|c|}
\hline & $\frac{\text { Sampel }}{A x}(0)$ & $\frac{\text { Sampel }}{\text { Mean (M) }}$ & $\begin{array}{l}\text { Srandar } \\
\text { Derias } \\
\text { (STDEV) }\end{array}$ & $\begin{array}{l}\text { T Statistik } \\
\text { (OSTDEV) }\end{array}$ & P Values \\
\hline $\begin{array}{l}\text { Kompetensi (Il)-> } \\
\text { Yotinasi(vI) }\end{array}$ & 0.556 & 0.605 & 0.193 & 2.836 & 0.002 \\
\hline $\begin{array}{l}\text { Kompetensi (rl) } \rightarrow \\
\text { Kineria Guru (v2) }\end{array}$ & 0.373 & 0.384 & 0.105 & 3567 & 0.000 \\
\hline $\begin{array}{l}\text { Gaya } \\
\text { Kepeaimpion } \\
\text { Iransformasiceal } \\
\text { (x) } \rightarrow \text { Motivasi } \\
\text { (v1) }\end{array}$ & 0.355 & 0.313 & 0.195 & 1.814 & 0.035 \\
\hline $\begin{array}{l}\text { Gaya } \\
\text { Kepeaimpiano } \\
\text { Iransformasional } \\
\text { (I2) }>\text { Kinerja } \\
\text { Guru (v2) }\end{array}$ & 0.317 & 0.323 & 0.060 & 5259 & 0.000 \\
\hline $\begin{array}{l}\text { Motivasi(vI) } \rightarrow \\
\text { Kinerja Gura (y2) }\end{array}$ & 0.357 & 0.342 & 0.112 & 3.178 & 0.001 \\
\hline
\end{tabular}

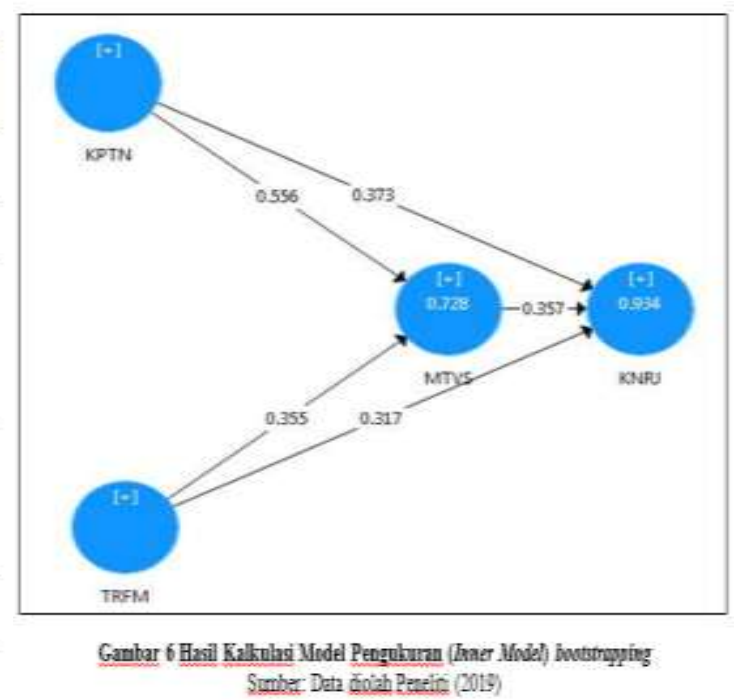

Based on Figure 6 the structural equation of this research can be formulated as follows:

Motivation $(Y 1)=0,556 r 1+0,355$ r2

Teachers Performance $(Y 2)=0,373$ r3 + 0,317 r $4+0,357 \beta$

Based on table 4 it can be concluded that:

1) Competence has an effect of 0,556 on motivation with a T-Statistic value of 2,886 and PValues of 0,002 .

2) Competence has an effect of 0,373 on teachers performance with a T-Statistic value of 3,567 and P-Values of 0,000 .

3) Transformational leadership style has an effect of 0,355 on motivation with a T-Statistic value of 2,886 and P-Values of 0,002 .

4) Transformational leadership style has an effect of 0,317 on teachers performance with a TStatistic value of 5,259 and P-Values of 0,000 .

Motivation has an effect of 0,357 on teachers performance with a T-Statistic value of 3,178 and PValues of 0,001 .

Simultaneous effect of competence, transformational leadership style on motivstion (MTVS) can be done by calculating the f statistic using the formula as in below.

$\mathrm{R}^{2}=0,728$ (MTVS)

F statistic $=\frac{\frac{R^{2}}{(k-1)}}{1-R^{2} /(n-k)}$

F statistic $=\frac{\frac{0.728}{(3-1)}}{1-0,728 /(52-3)}$

F statistic $=0,364 / 0,006$

F statistic $=65,574$

Ni lai $F$ table at $(D F 1=3-1 ; D F 2=52-3)$ alpha 0,1 is 2,20 . This means that $f$ statistic $>\mathrm{f}$ table then there is a simultaneous influence of competence and transformational leadership style on motivation. Simultaneous influence of variable competence, transformational leadership style and motivation on teachers performance (KNRJ) can be done by calculating the $\mathrm{f}$ statistic using the formula as in below.

$$
\begin{aligned}
& \mathrm{R}^{2}=0,934(\mathrm{KNRJ}) \\
& \mathrm{F} \text { hitung }=\frac{\frac{R^{2}}{(k-1)}}{1-R^{2} /(n-k)}
\end{aligned}
$$


F hitung $=\frac{\frac{0.934}{(4-1)}}{1-0,934 /(52-4)}$

F hitung $=0,311 / 0,001$

F hitung $=226,424$

The $\mathrm{F}$ value of the table at $(\mathrm{df} 1=4-1 ; \mathrm{df} 2=52-4)$ alpha 0,1 is 2,07 . This means that $\mathrm{f}$ statistic $>\mathrm{f}$ table then there is a simultaneous influence of competence, transformational leadership style, and motivation on teachers performance. Based on these calculations, it means that $f$ statistic $>\mathrm{f}$ table, then $\mathrm{H} 5$ and $\mathrm{H} 6$ are accepted.

Tabel 5. Pengaruh tidak langsung (indirect effect) Yariabel Independen Terhadap Yariabel Dependen

\begin{tabular}{|c|c|c|c|c|c|c|}
\hline & $\begin{array}{l}\text { Sampel } \\
\text { Asli } \\
\text { (O) }\end{array}$ & $\begin{array}{l}\text { Sampel } \\
\text { Mean } \\
\text { (M) }\end{array}$ & $\begin{array}{l}\text { Standar } \\
\text { Deviasi } \\
\text { (STDEV) }\end{array}$ & $\begin{array}{l}\text { T Statistik } \\
\text { (O/STDEV) }\end{array}$ & $\begin{array}{c}T \\
\text { Tabel }\end{array}$ & P Values \\
\hline $\begin{array}{l}\text { Kompetensi(xl) - } \\
>\text { Motivasi (y1) } \rightarrow \\
\text { Kineria (y2) }\end{array}$ & 0.199 & 0.201 & 0.094 & 2.122 & 1.299 & 0.017 \\
\hline $\begin{array}{l}\text { Gaya } \\
\text { kepemimpinan } \\
\text { Transformasional } \\
\text { (x2) } \rightarrow \text { Motixasi } \\
\text { (y1) } \rightarrow \text { Kinerja } \\
\text { (y2) }\end{array}$ & 0.127 & 0.112 & 0.082 & 1.547 & 1.299 & 0.061 \\
\hline
\end{tabular}

1) Path coefficient value of direct influence of competence on teachers performance $0,373>$ path coefficient value of indirect influence on the teachers performance of competence is 0,199 and value of $p$ value $0,017<0,1$ with a $\mathrm{T}$ value of $2,122>\mathrm{T}$ Table 1,299 , it is concluded that indirect effect of competence on teachers performance is not mediated by motivation variables,

2) Path coefficient value of direct influence of transformational leadership style on teachers performance $0,317>$ path coefficient value of indirect effect of transformational leadership style on teachers performance is 0,127 and the value of $p$ value is $0,061<0,1$ with a $\mathrm{T}$ value of 1,547 $>\mathrm{T}$ Table 1,299, it is concluded that indirect effect of transformational leadership on teachers performance is not mediated by motivational variables.

\section{Correlation between dimensions}

Matrix correlation between dimensions is intended to determine the dimensions of the independent variable (competence and transformational leadership style) which has the highest correlation value with the dependent variable dimensions Y1 (motivation) and the dependent variable dimensions Y2 (teachers performance) and also to determine the dimensions of the dependent variable Y1 (motivation) which has the highest correlation value with the dependent variable dimension Y2 (teachers performance).

\begin{tabular}{|c|c|c|c|c|}
\hline \multirow{2}{*}{ Fariathel } & \multirow{2}{*}{ Dineas: } & \multicolumn{3}{|c|}{ Mlithat (MI) } \\
\hline & & $\begin{array}{l}\text { Ketvribas } \\
\text { alun prtitas }\end{array}$ & $\begin{array}{c}\text { Krbutalas alas } \\
\text { vfiflasi }\end{array}$ & 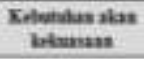 \\
\hline \multirow{4}{*}{ S-mpenai (XI) } & $\begin{array}{l}\text { Eenonimi } \\
\text { Roturati }\end{array}$ & $6 m$ & eses & est \\
\hline & 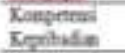 & ess & 072 & 0.45 \\
\hline & $\begin{array}{l}\text { Eomperad } \\
\text { Sorni }\end{array}$ & 0753 & e.t54 & 0753 \\
\hline & $\begin{array}{l}\text { Kenpermi } \\
\text { hofesical }\end{array}$ & ens & eras & $65 i$ \\
\hline \multirow{4}{*}{ 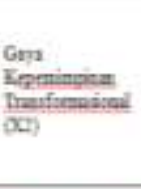 } & Fergundideal & 0799 & Aat? & c.5s: \\
\hline & $\begin{array}{l}\text { Mitiva } \\
\text { kepiniend }\end{array}$ & 2534 & 072 & OกI \\
\hline & Stevian & 62 & 0.50 & 0.704 \\
\hline & $\begin{array}{l}\text { Pentancusen } \\
\text { bedided }\end{array}$ & 0.51 & 2712 & 0.714 \\
\hline
\end{tabular}

\begin{tabular}{|c|c|c|c|c|c|c|}
\hline \multirow[b]{2}{*}{ Teraber } & \multirow[b]{2}{*}{ Dement } & \multicolumn{5}{|c|}{ smele Caen as } \\
\hline & & nom & makns & Katas & 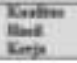 & sit \\
\hline \multirow{4}{*}{ Saqme $\alpha 1$} & Ponter & Exता & in & 벵 & $\sin$ & ane \\
\hline & Expletis & $\operatorname{sตn}$ & wet & ins & 47 & as: \\
\hline & $\operatorname{sen}$ & 270 & ave & anet & ยพ & 47 \\
\hline & Keve & $4 \pi$ & $2+14$ & ins & $\sin$ & $a+1$ \\
\hline \multirow{4}{*}{ 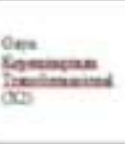 } & Repind lited & te & $\operatorname{ten}$ & 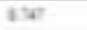 & the & 201 \\
\hline & Mand & $s=$ & $\mathrm{kn}$ & ante & tain & anu \\
\hline & 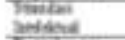 & 470 & $\sin$ & tas & in & $4 \% 7$ \\
\hline & Trownin & 273 & atat & ant & the & ane \\
\hline \multirow{3}{*}{ Hutra 65} & Cowation & tou & $t=$ & $\tan$ & trou & $2 \mathrm{an}$ \\
\hline & $\begin{array}{l}\text { Tind } \\
\sin A=1\end{array}$ & 400 & $2 \div 4$ & tont & $m$ & ani \\
\hline & Nen & $t=$ & stm & $x$ & ant & ase \\
\hline
\end{tabular}

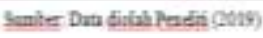


From Tables 6 and 7 above it can be concluded as follows:

1) On the competence variable on the motivation variable, the highest correlation dimension is personality competence to the dimension of need for achievement 0,861 . While the lowest dimension correlation on this variable is personality competence to the dimensions of need for affiliation, which is 0,725 .

2) On the transformational leadership style variable on the motivation variable, the highest correlation dimension is intellectual stimulation of need for achievement dimension, amounting to 0,843 . While the lowest correlation dimension on this variable is the ideal influence dimension to the dimension of the need for power, which is 0,585 .

3) On the competence variable on teachers performance variable, the highest correlation dimension is the pedagogical competence on the timeliness dimension, amounting to 0,881 . While the lowest correlation dimension on this variable is the dimension of personality competence to ability, which is equal to 0,671 .

4) On the variable of transformational leadership style on teachers performance variables, the highest correlation dimension is inspirational motivation on the dimensions of work quality, amounting to 0,866 . While the lowest dimension correlation on this variable is the ideal influence dimension on initiatives, which is equal to 0,634 .

5) On the motivation variable on teachers performance variables, the highest correlation dimension is need for achievement on the timeliness dimension, amounting to 0,895 . While the lowest correlation dimension on this variable is the dimension of need for power to ability, which is equal to 0,663 .

\section{FINDINGS AND DISCUSSION}

The effect of each research variable is related to the theory and a review of previous research can be explained in the discussion of the results of the research in detail as follows.

\section{Effect of Competence on Motivation (Hypothesis 1)}

$P$-value competence variable on work motivation (KPTN $\rightarrow$ MTVS) is significant with $p$ value of 0,002 , T statistic of 2,886 > 1,299 and the original sample is positive, then Ho is rejected and it was concluded that the competence of positive and significant effect on work motivation, if the teachers have good competence in carrying out basic tasks and functions, then the teachers will always have high work motivation in carrying out his work, and vice versa. This is consistent with the research conducted by Rahim et. al. (2017) and Indarti (2018) which shows the results that competence has a positive and significant influence on work motivation.

\section{Effect of Transformational Leadership Style on Motivation (Hypothesis 2)}

$P$-value transformational leadership style variable on work motivation (TRFM $\rightarrow$ MTVS) is significant with a $p$ value of 0,035 , T statistic of 1,814 >1,299 and the original sample is positive, then Ho is rejected and it is concluded that the transformational leadership style has a positive and significant effect on work motivation, the greater the transformational leadership style applied by school leaders/principals to teachers, the higher the teachers's work motivation, and vice versa. Transformational leadership style has a way to motivate followers by giving more encouragement to followers, giving examples to prioritize groups rather than individuals for the good of the group, and provide appropriate facilities for followers to be more enthusiastic in doing work. Transformational leadership is a determining factor that influences employee attitudes, perceptions and behaviors with increased trust in leaders, motivation, job satisfaction and being able to reduce a number of conflicts that often occur within an organization (Nugroho and Aima, 2018). This was reinforced by the research of Ahmad et. al . (2014) and Hussain et. al . (2017) which shows the results that the transformational leadership style has a positive and significant influence on work motivation. 
Effect of Competence on Teachers Performance (Hypothesis 3)

$P$-value competence variable on the teachers performance (KPTN $\rightarrow$ KNRJ) is significant with a value of $p$ value of 0,000 , T statistic of 3,567>1,299 and the original sample is positive, then Ho is rejected and it was concluded that the competence has a positive and significant effect on the teachers performance, the corresponding competence with the ability of teachers, the higher the teachers's performance, and vice versa. A person's performance can be improved if the competence of existing human resources in the organization is increased. In this case the performance can be improved by paying attention to each dimension of Competence that must be possessed by teachers, namely pedagogical competence, personality competence, professional competence, and social competence. This was reinforced by the research of Otoo and Mishra (2018) and Meswantri and Awaludin (2018) which showed the results that competence had a positive and significant influence on teachers performance.

\section{Effect of Transformational Leadership Styles on Teachers Performance (Hypothesis 4)}

$P$-value transformational leadership style variable on teachers performance (TRFM $\rightarrow$ KNRJ) is significant with a $p$ value of 0,000 , T statistic of 5,259 > 1,299 and the original sample is positive, then $\mathrm{Ho}$ is rejected and it is concluded that transformational leadership style has a positive and significant effect on teachers performance, the greater the transformational leadership style applied by leaders/principals to teachers, the higher the teachers's performance, and vice versa. Transformational leadership strives to inspire exceptional performance. If the leader can influence and direct the karyaw an u ntuk achieve the objectives of the company, the employee will work well and improve its performance. This was reinforced by the research of Sinaga et. al. (2018), Nugroho and Aima (2018), and Umaternate and Elmi (2017) who showed the results that the transformational leadership style had a positive and significant influence on teachers performance.

Effect of Competence and Transformational Leadership Styles on Motivation (Hypothesis 5)

The $R^{2}$ value motivation variable is 0,728 with $F$ statistic of 65,574 , because the $F$ statistic $>F$ table $(3,187)$, it is concluded that the variable of competence and transformational leadership style simultaneously has a significant effect on the motivation variable with a large influence of simultance of $72,8 \%$ while the remaining $28,2 \%$ of the motivation of 01 and 02 North Petukangan elementary school teachers was influenced by other factors beyond the competence and transformational leadership style.

Assuming there is a link between variables of competence and transformational leadership styles together with motivation. Based on the results of the research that has been informed above, that each variable has a positive influence in influencing the work motivation of a teachers. Thus, the higher the level of competence and transformational leadership style, the higher the motivation will be, and vice versa.

Effect of Competence, Transformational Leadership Styles, and Motivation on Teachers Performance (Hypothesis 6)

The $\mathrm{R}^{2}$ value of teachers performance variable is 0,934 with $\mathrm{F}$ statistic of 226,424 , because the value of $\mathrm{F}$ statistic $>\mathrm{F}$ table it is concluded that the variables of competence, transformational leadership style, and motivation simultaneously have a significant effect on motivation variables with a large simultaneous influence of $93,4 \%$, this shows that $93,4 \%$ of the variance in the performance of 01 and 02 North Petukangan elementary school teachers is influenced by competence, transformational leadership style and motivation, while the remaining 6,6\% performance of 01 and 02 North Petukangan elementary school teachers is influenced by factors outside competence, transformational leadership style and motivation.

Assumptions are interrelationships between competence variables, transformational leadership styles, and motivation together on teachers performance. Based on the results of the research that has been stated above that each variable has a positive influence in influencing the performance of a teachers. Thus, the higher the level of competence, transformational leadership style, and motivation, the higher the performance will be, and vice versa. 


\section{Effect of Motivation on Teachers Performance (Hypothesis 7)}

$P$-value of the influence of motivation variable on performance (MTVS $\rightarrow \mathrm{KNRJ}$ ) is significant with $\mathrm{p}$ value of $0,001, \mathrm{~T}$ statistic is 3,178 $>1,299$ and original sample is positive then Ho is rejected and it is concluded that motivation has a positive and significant effect on performance, the higher motivation to work the teachers the higher the teachers's performance, conversely the teachers whose performance is low is due to low work motivation.

The teachers as one part of teaching and learning activities has an important role in determining the success of learning because the main function of the teachers is to design, manage, implement and evaluate learning. Therefore, fostering teachers work motivation is very important for achieving maximum performance. This is reinforced by the research of Aima, Adam and Ali (2017), Nugroho et. al. (2015) and Shahzadi et. al. (2014) which shows the results that motivation provides a positive and significant effect on teachers performance.

Motivation Mediates Competence and Transformational Leadership Styles on Teachers Performance (Hypothesis 8)

Path coefficient value of the direct influence of competence on teachers performance $0,373>$ path coefficient value of indirect effect of competence on teachers performance is 0,199 then competence on teachers performance is not mediated by motivation variable and path coefficient value of direct influence of transformational leadership style on teachers performance 0,317 > path coefficient value of indirect influence of style transformational leadership on teachers performance is 0,127 then the transformational leadership style on teachers performance is not mediated by motivational variable.

Based on the theoretical study above, it can be indicated that motivation does not mediate competence and transformational leadership style on performance. This is not in accordance with the results of research conducted by Rinawati and Ingsih (2014) and Rahim et. al. (2017) which shows that motivation is able to mediate competence variable on performance variable and Amalia et. al. (2016) which shows that motivation is able to mediate variable of transformational leadership style on performance variable.

In this study it is known that the direct effect of competence and transformational leadership style on performance is greater when compared to its indirect effect. This is relevant to the conditions in the field because the competencies of each teacher are different. Teachers are required to continue to develop their competencies. Competence in the form of hardskill and soft skills possessed by a teacher is very important. Softskill itself will not run perfectly if it is not accompanied by hardskill, and vice versa. softskill itself will be born if someone has a great motivation to change better than before (Elmi, 2018). If the teacher has high competence, the teacher will be able to improve his performance well. So, it can be said that the level of competency of a teacher will affect the level of performance of a teacher. To get an accurate performance appraisal, the assessment should not only be done by the principal but also involves the teacher as a colleague and supervisor. The role of transformational leadership style that is applied by each leader/principal from one period to another also varies so that it affects the performance of 01 and 02 North Petukangan elementary school teachers. The principal's role as a leader determines the level of performance of teachers in schools and can provide guidance in improving the quality of performance. The performance of teachers will be better if controlled, always evaluated, and get motivation from the principal.

\section{CONCLUSION AND SUGGESTION}

\section{Conclusion}

Based on the results of the research and discussion in the previous chapters, several conclusions can be made as follows:

1) Competence has a significant positive effect on motivation, with the personality competence dimension being the strongest influence.

2) Transformational leadership style has a significant positive effect on motivation, with the dimensions of intellectual stimulation having the strongest influence. 
3) Competence has a significant positive effect on teachers performance, with the most influential dimension of pedagogical competence.

4) Transformational leadership style has a significant positive effect on teachers performance, with the inspirational motivation dimension being the strongest influence.

5) Competence and transformational leadership style simultaneously have a significant positive effect on motivation.

6) Competence, transformational leadership style, and motivation simultaneously have a significant positive effect on teachers performance.

7) Motivation has a significant positive effect on teachers performance.

8) Motivation does not mediate the competence and transformational leadership styles on teachers performance. Based on the results of the research and discussion in the previous chapters, some conclusions and recommendations can be drawn.

\section{Suggestions}

Based on the results of the analysis of the discussion and some of the conclusions above, the suggestions that can be given to supplement the results of this study are as follows:

1) A Competence improvement program needs to be made in which it can be carried out by covering activities aimed at improving and growing abilities, attitudes, and skills. From these activities, teachers are expected to produce changes in teachers behavior that has an impact on improving teachers performance in the teaching and learning process in the classroom.

2) Training needs to be carried out internally in schools or other designated places to organize training. The training material must be presented with current issues that are developing and keep abreast of current science and technology. The ability of teachers to manage and use digital technology to obtain and manage information is very important in teaching and learning activities.

3) School principals need to improve academic supervision activities by directing, guiding, motivating, facilitating and influencing teachers in the process of learning activities and providing guidance services in order to achieve school goals. Principals need to inspire enthusiasm for cooperation, enthusiasm, and optimism among colleagues and their work environment. Principals as academic supervision must provide support to teachers to be more innovative and creative by encouraging teachers to ask assumptions, bring up new ideas and methods, and present old approaches in a new perspective.

4) Give awards to achievements to teachers who have good performance achievements, this award can be made based on an agreement between fellow teachers and the principal. The award can be made based on an assessment of aspects or assessment of the teachers in providing teaching to students assessed by students and parents.

REFERENCE

UNDANG-UNDANG REPUBLIK INDONESIA NOMOR 20 TAHUN 2003 TENTANG SISTEM PENDIDIKAN NASIONAL. (2003). Jakarta.

Peraturan Pemerintah Republik Indonesia Nomor 74 Tahun 2008 Tentang Guru. (2008). Jakarta.

Peraturan Pemerintah Republik Indonesia Nomor. 19 tahun 2017 Tentang Perubahan Atas peraturan Pemerintah Nomor 74 Tahun 2008 Tentang Guru. (2017). Jakarta.

Ahmad, F., Abbas, T., Latif, S., \& Rasheed, A. (2014). Impact of Transformational Leadership on Employee Motivation in Telecommunication Sector. Journal of Management Policies and Practices Vol. 2, No. 2, 11-25.

Aima, H., Adam, R., \& Ali, H. (2017). Model of Employee Performance: Competence Analysis and Motivation (Case Study at PT. Bank Bukopin, Tbk Center). Journal of Research in Business and Management, 49-59.

Asf, J., \& Mustofa, S. (2013). Supervisi Pendidikan. Cet ke-1. Yogyakarta: Ar-Ruzz Media.

Avolio, B. J., \& Bass, B. M. (2002). DEVELOPING POTENTIAL ACROSS FULL RANGE OF LEADERSHIP Cases on Transactional and Transformational Leadership. New Jersey: Lawrence Erlbaum Associates. Inc. 
Elmi, F. (2018). Telisik Manajemen Sumber Daya Manusia. Jakarta: Mitra Wacana Media.

Ganjar, S., \& Aima, M. H. (2018). The Influences Of Transformational Leadership and Compensation To Employee Performance On Their Motivation And The Implementation at X Institution. International Journal of Scientific and Research Publications, 352-359.

Hair, J. F., Black, W. C., Babin, B. J., \& Anderson, R. E. (2010). Multivariate Data Analysis 7th ed. New Jersey: Pearson Prentice Hall.

Indarti, Y. D. (2018). The Effect Of Competence And Compensation To Motivation Of Employees And Its Impact On Employee Performance In The Personnel And Training Board Of Karawang Regency. AFEBI Management and Business Review (AMBR) Vol.03 No.01, 52-68.

Kasmir. (2017). Manajemen Sumber Daya Manusia (Teori dan Praktik). Cet. 2. Jakarta: PT. Raja Grafindo Persada.

Mangkunegara, A. A. (2015). Manajemen Sumber Daya Manusia Perusahaan. Bandung: PT. Remaja Rosdakarya.

Marwansyah. (2014). Manajemen Sumber Daya Manusia Edisi Ke 2. Bandung: CV. Alfabeta.

Meswantri, \& Awaludin. (2018). Determinant of Employee Engagement and its Implications on Employee Performance. International Review of Management and Marketing, 8(3), 36-44.

Nugroho, A., Elmi, F., \& Suharno. (2015). The Influence Of Leadership Behavior, Organizational Climate, Intrinsic Motivation, And Engagement As Mediating Variables On The Performance Of Permanent Lecturers: A Study In A Private University In Region III Of Special Region Of Jakarta. International Journal of Humanities and Social Science Invention, 85-92.

Otoo, F. N., \& Mishra, M. (2018). Impact of Human Resource Management (HRM) Practices on Hotel Industry's Performance: The Mediating role of Employee Competencies. Indian Journal of Commerce \& Management Studies Volume IX Issue 2, 17-29.

Rahim, A., Syech, S., \& Zahari, M. (2017). Pengaruh Lingkungan Kerja Dan Kompetensi Terhadap Motivasi Kerja Serta Dampaknya Terhadap Kinerja Pegawai Pada Dinas Pendidikan Kabupaten Tanjung Jabung Timur. J-MAS Vol.2 No.2, 133-149.

Riduwan. (2014). Metode \& Teknik Menyusun Proposal Penelitian. Bandung: Alfabeta.

Rinawati, S. I., \& Ingsih, K. (2014). Pengaruh Lingkungan Kerja Dan Kompetensi Terhadap Kinerja Karyawan Dengan Motivasi Sebagai Variabel Intervening Pada Satuan Kerja Non Vertikan Tertentu (SNVT) Kementrian. Jurnal Universitas Dian Nuswantoro.

Rivai, V., Ramly, M., Mutis, T., \& Arafah, W. (2014). Manajemen Sumber Daya Manusia Untuk Perusahaan. Dari Teori Ke Praktik. Jakarta: Raja Grafindo Persada.

Robbins, S. P., \& Judge, T. A. (2015). Perilaku Organisasi Edisi 16. Jakarta: Salemba Empat.

Shahzadi, I., Javed, A., Pirzada, S. S., Nasreen, S., \& Khanam, F. (2014). Impact of Employee Motivation on Employee Performance. European Journal of Business and Management Vol.6, No.23, 159-166.

Sinaga, H. G., Asmawi, M., Madhakomala, R., \& Suratman, A. (2018). Effect of Change in Management, Organizational Culture and Transformational Leadership on Employee Performance PT. Adhya Tirta Batam. International Review of Management and Marketing, $8(6), 15-23$.

Sugiyono. (2016). Metode Penelitian Kuantitatif, Kualitatif, dan R\&D. Bandung: CV. Alfabeta.

Sutrisno, E. (2016). Manajemen Sumber Daya Manusia. Jakarta: Prenadamedia Group.

Umaternate, A. R., \& Elmi, F. (2017). Pengaruh Gaya Kepemimpinan Transformasional, Disiplin Kerja, Dan Penempatan Kerja Terhadap Kienrja Karyawan FPG Insurance. Jurnal SWOT, 273-287.

Wiratih, H. W., \& Aima, M. H. (2017). Teachers As A Transformer Of Cognitive And Wisdom For Sustainable Character Development. Journal of Advance Research in Social Science and Humanities (ISSN: 2208-2387), 01-11.

Yukl, G. A. (2015). Kepemimpinan Dalam Organisasi (edisi ketujuh). Jakarta: PT. Indeks. 